\title{
DFFB wt Allele
}

National Cancer Institute

\section{Source}

National Cancer Institute. DFFB wt Allele. NCI Thesaurus. Code C126526.

Human DFFB wild-type allele is located in the vicinity of 1 p36.3 and is approximately $28 \mathrm{~kb}$ in length. This allele, which encodes DNA fragmentation factor subunit beta protein, plays a role in the regulation of DNA fragmentation and chromosome condensation during apoptosis. 